Check for updates

Cite this: RSC Adv., 2018, 8, 19539

\title{
4-Hydroxybenzyl alcohol derivatives and their sedative-hypnotic activities
}

\author{
Hong-yan Zhu, ${ }^{a}$ Di Zhang, ${ }^{a}$ Qi Zhang, ${ }^{\text {b }}$ Yan Zhao, DD *a Zhong-mei He, ${ }^{a}$ \\ Yu-gang Gao*a and Lian-xue Zhang ${ }^{a}$
}

4-Hydroxybenzyl alcohol (HBA), one of the characteristic active components of Gastrodia elata, exhibits obvious effects on the human central nervous system. In order to acquire compounds with superior bioactivity, 10 derivatives of HBA were synthesized from HBA and carboxylic acids. The sedative effects of the 10 HBA derivatives were evaluated using a spontaneous locomotor activity test (SLT) in mice, and their hypnotic effects were determined to be synergistic with pentobarbital-induced sleep. The results showed that 4-hydroxybenzyl alcohol 3-furancarboxylic acid diester (2FHBA, $10 \mathrm{mg} \mathrm{kg}^{-1}$ ) exhibited the strongest sedative-hypnotic activity among HBA and its derivatives, and 2FHBA could reverse the insomnia caused by $p$-chlorophenylalanine ( $p C P A)$, flumazenil (FLU) and thiosemicarbazide (TSC). Meanwhile, 2FHBA and 5-hydroxytryptophan (5-HTP) showed a synergistic effect. The results suggested that 2FHBA might be a potential agent against insomnia, which might be mediated by the serotonergic and GABAergic systems.

Received 6th March 2018

Accepted 4th May 2018

DOI: 10.1039/c8ra01972j

rsc.li/rsc-advances

Hydroxybenzyl alcohol (HBA), also named as gastrodigenin, is

\section{Introduction}

Today, almost half of human beings suffer from sleeping disturbance all over the world, not only old people but also young people, due to the excessive stress in their lives. ${ }^{1}$ Difficulty getting to sleep, easily waking up and poor sleep quality are all symptoms associated with insomnia, which appears to be very prevalent and seriously threatens human health. If there is no effective control, insomnia will develop into a major depressive disorder. Therefore, it is necessary to search for potent medicines with effective sedative and hypnotic activities. Natural products have become an important source of bioactive lead compounds for drug discovery, especially their derivatives through synthetic transformation or structural modification, which has occupied a leading position recently. ${ }^{2}$

Gastrodia elata ( $G$. elata), recorded as the stem tubers of $G$. elata Blume in Chinese pharmacopoeia, has been found to possess a wide range of biological activities, including sedative and hypnotic, ${ }^{3,4}$ antiepileptic and anticonvulsive, ${ }^{5,6}$ anti-anxiety and antidepressant, ${ }^{7,8}$ neuroprotective, ${ }^{9}$ anti-cardio-cerebralvascular disease, ${ }^{10}$ antipsychotic, ${ }^{11}$ anti-vertigo, ${ }^{12}$ anticoagulant and antithrombotic, ${ }^{13}$ anti-atherosclerotic, ${ }^{14}$ antihypertensive, ${ }^{15}$ anti-inflammatory and analgesic, ${ }^{16,17}$ memory improving and anti-aging, ${ }^{18}$ antivirus ${ }^{19}$ and antitumor ${ }^{20}$ activities and so on. 4-

${ }^{a}$ College of Chinese Medicinal Materials, Jilin Agricultural University, Changchun 130118, Jilin, China. E-mail: zhaoyan@jlau.edu.cn; gaoyugang_2006@163.com; Fax: +86431 84533358; Tel: +8643184533358

${ }^{b}$ The Fiftieth Middle School of Daqing, Daqing 163000, China the characteristic and main active component of G. elata. Gastrodin (GAS) is another chief active ingredient of G. elata, and studies have also reported that GAS is metabolized to HBA in the body and then plays pharmacological roles. ${ }^{21}$ Meanwhile, HBA was chosen as one of the standard compounds to evaluate the quality of G. elata. ${ }^{22}$ Modern pharmacological experiments have demonstrated that HBA apparently possesses the ability to adjust the central nervous system, including sedation, ${ }^{23}$ anticonvulsion, ${ }^{23}$ anti-depressant, ${ }^{24}$ and anti-neuroinflammation activities, ${ }^{25}$ facilitating memory and neuroprotection, ${ }^{26,27}$ and it is often used as a precursor compound through structural modification to discover more active compounds. It has been reported that the derivatives of HBA substituted with amino acids, phosphate and sulfonate display excellent hepatoprotective, anti-cancer and inhibition of rat testicular P-450 ${ }_{17 \alpha}$ activities, respectively. ${ }^{28-30}$

Carboxylic acids are usually selected to be synthesized with compounds with hydroxyl groups to obtain better biological activity esters. Some bioactive compounds have been synthesized by our team in recent years, like ergosteryl 2-naphthoate ${ }^{31}$ and arctigenin $\beta$-indolylacetate, ${ }^{32}$ which showed excellent antitumor effects. The aim of this study was to find new compounds with potentially sedative and hypnotic activities by synthesizing derivatives of HBA with carboxylic acids. Behavioral pharmacological tests, including the spontaneous locomotor activity test and the pentobarbital-induced sleep test, were employed to evaluate their biological activities. Furthermore, the possible mechanism was also devised. 


\section{Materials and method}

\subsection{Animals}

Mice weighing 18-22 g were supplied by Changchun Yisi Experimental Animal Technology Co. Ltd. The animals were kept under standard laboratory conditions (temperature $25 \pm$ $2{ }^{\circ} \mathrm{C}$, relative humidity $60 \pm 5 \%, 12 \mathrm{~h}$ light $/ 12 \mathrm{~h}$ dark cycle with light on at 7:00 a.m.) with food and tap water available ad libitum for the duration of the study. After 1 week of acclimatization, all mice were randomly divided into different groups. All tests were performed in accordance with the Guide for Animal Experimentation of Jilin Agricultural University. The protocol was approved by the Jilin Agricultural University Institutional Animal Care and Use Committee. Every effort was made to minimize the number of animals used and any pain and discomfort experienced by the subjects.

\subsection{Drugs and reagents}

HBA, 3-furoic acid, 2-naphthoic acid, (Z)-9-octadecanoic acid (oleic acid), 2,4-hexadienoic acid (sorbic acid), octadecadienoic acid (linoleic acid), dodecanoic acid (lauric acid) and benzoic acid were purchased from Sinopharm Chemical Reagent Co. Ltd. (Shanghai, China). 4-Dimethylaminopyridine (DMAP) and 1-ethylethyl-3-(3-dimethyllaminopropyl) carbodiimide hydrochloride (EDCI) were purchased from Civi Chem Co. Ltd (Shanghai, China). The HBA derivatives were synthesized by us. Dichloromethane was acquired from Damao Chem Co. Ltd. (Tianjin, China). Diazepam (DZP) was provided by Zhenxing Pharma Co. Ltd. (Taiyuan, China). Sodium pentobarbital was purchased from Merck Co. Ltd. (Shanghai, China). The flumazenil (FLU) injection was produced by Lingkang Co. Ltd. (Hainan, China). $p$-Chlorophenylalanine (pCPA), thiosemicarbazide (TSC) and 5-hydroxytryptophan (5-HTP) were all purchased from Melone Pharma Co. Ltd. (Dalian, China). All the reagents used in this study were of analytical grade.

\subsection{Synthesis}

The experimental procedure is described taking 4-hydroxybenzyl alcohol 3-furoate (FHBA) and 4-hydroxybenzyl alcohol 3furancarboxylic acid diester (2FHBA) as an example. 3-Furancarboxylic acid (6 mmol) and EDCI $(8 \mathrm{mmol})$ were dissolved in $10 \mathrm{~mL}$ of dichloromethane and stirred for 10 minutes; then, $10 \mathrm{~mL}$ of dichloromethane solution containing HBA (4 mmol) and DMAP ( $4.8 \mathrm{mmol}$ ) was added to the mixture. After dissolution, the mixture was heated to reflux at $60{ }^{\circ} \mathrm{C}$ for 6 hours and the solvent was removed under reduced pressure. The residue was purified by silica gel chromatography and eluted with petroleum ether/acetone $(6: 1, \mathrm{v} / \mathrm{v})$ to yield the product 2FHBA and FHBA. The synthesis of the other derivatives was similar to that of FHBA and 2FHBA.

\subsection{Structural identification}

The structures of the HBA derivatives were determined by IR, NMR and MS analysis. FTIR analysis was performed on a WGH-30/30A double beam infrared spectrophotometer
(Gangdong Sci. \& Tech. Development Co., Ltd. Tianjin, China). NMR spectra were recorded on a Varian Mercury $300 \mathrm{MHz}$ NMR spectrometer equipped with an Oxford Instruments Ltd. superconducting magnet (Palo Alto, CA, USA). The HRMS was measured using a Q-Exactive Electrospray Orbitrap High Resolution Mass Spectrometer (Thermo-Fisher, USA). Melting point analysis was performed in an X-4 micro melting point apparatus (Tech Instrument Co., Ltd., Beijing, China). Specific conclusions are described in detail in the Results section.

\subsection{Treatment}

Ten derivatives of HBA and DZP were blended with $0.05 \%$ sodium carboxymethyl cellulose (CMC-Na)/physiological saline and administered 30 minutes prior to the locomotor activity test or pentobarbital administration. Sodium pentobarbital was dissolved in physiological saline, using $28 \mathrm{mg} \mathrm{kg}^{-1}$ (intraperitoneally, i.p.) as the sub-hypnotic dose and $42 \mathrm{mg} \mathrm{kg}^{-1}$ (i.p.) as the hypnotic dose, which could generate a $100 \%$ rate of sleep onset. $p$ CPA (100 $\mathrm{mg} \mathrm{kg}^{-1}$, i.p.) was administered continuously for 4 days to obtain the mouse insomnia model. After the insomnia model was successfully established, 2FHBA was administered for observation. TSC ( $8 \mathrm{mg} \mathrm{kg}^{-1}$, i.p.), diluted in $0.9 \%$ physiological saline, was injected $30 \mathrm{~min}$ before the administration of 2FHBA. 5-HTP $\left(2.5 \mathrm{mg} \mathrm{kg}^{-1}\right.$, i.p.) also diluted in $0.9 \%$ physiological saline was given $15 \mathrm{~min}$ prior to pentobarbital administration. FLU injection was also administrated 15 min prior to the administration of pentobarbital to obtain an insomnia model. All the drug solutions were freshly prepared before use.

\subsection{Spontaneous locomotor activity test (SLT)}

The sedative effects of HBA and its derivatives were assessed by detecting the spontaneous locomotor activity of mice. Locomotor activity and standing numbers could be calculated using the ZZ-6 locomotor activity tester (Taimeng Software Co. Ltd., Chengdu, China), which consisted of a microcomputer vehicle system and six separable reaction jars that possessed 36 points of infrared array probes. $30 \mathrm{~min}$ after oral administration of HBA and its derivatives and DZP respectively, mice were placed separately in the locomotor activity tester. After adapting for $5 \mathrm{~min}$, the locomotor activity of each mouse was recorded for $5 \mathrm{~min}$. After each testing session, the enclosure was thoroughly cleaned with $70 \%$ ethanol.

\subsection{Pentobarbital-induced sleep test}

Experiments were carried out between 8:00 a.m. and 12:00 a.m. Following sodium pentobarbital injection, each mouse was observed for the onset of sleep. When the mice lost their righting reflex for over $60 \mathrm{~s}$, they were considered to be asleep. The loss of the righting reflex was defined as a failure of the mouse to right itself for at least $15 \mathrm{~s}$ after being placed on its back. Sleep latency was recorded as the time of pentobarbital injection to the time of sleep onset, and the sleep duration was defined as the elapsed time between the righting reflex loss and recovery. 


\subsection{Acute toxicity test}

The acute toxicity of 2FHBA was investigated according to the Organization for Economic Cooperation and Development guideline 423 (OECD423). ${ }^{33} 40$ mice were randomly divided into four groups with 5 males and 5 females per group. 2FHBA was blended with $0.05 \%$ sodium carboxymethyl cellulose (CMC-Na)/ physiological saline and given orally only once at doses of 1000 , 2000 and $5000 \mathrm{mg} \mathrm{kg}^{-1}$ for detailed assessment of signs of toxicity (e.g., hypo-activity, breathing difficulty, convulsion and abnormal movements). The control group only received the same volume of vehicle. All groups were carefully observed for mortality and changes in general behavior for the first $24 \mathrm{~h}$ and for a total of 14 days. The $\mathrm{LD}_{50}$ value was determined according to the method described by the OECD Guideline 423 .

\subsection{Biochemical measurements}

The brains of the mice were washed with ice-cold physiological saline and homogenized, shaken for $10 \mathrm{~s}$ and centrifuged at $10000 \times g$ for $10 \mathrm{~min}$ at $4{ }^{\circ} \mathrm{C}$. The monoamine neurotransmitters including 5-HT and GABA were measured according to the instructions of competitive enzyme-linked immunosorbent assay kits, which were purchased from US R\&D Systems, Ltd. (Minneapolis, USA).

\subsection{Statistical analysis}

All values were expressed as mean \pm S.D. The data were statistically analyzed using the $t$-test and one-way analyses of variance (ANOVAs), followed by Tukey's post-hoc multiple comparison test. A value of $p<0.05$ was considered statistically significant.

\section{Results}

\subsection{Chemistry}

The HBA derivatives (Fig. 1) were obtained via the reaction of HBA with carboxylic acids in dichloromethane at a temperature of $60^{\circ} \mathrm{C}$ by reflux. DMAP was used as a catalyst. EDCI reacts first with the acid to form an activated carboxylic acid and then this activated carboxylic acid reacts with HBA to afford the derivatives. The products were isolated using a silica gel column. IR and NMR were used to identify the molecular structure of the newly synthesized HBA esters. HRMS (ESI) was used to determine the molecular weight of the derivatives. In the IR spectra of the derivatives, the characteristic peaks of the carbonyl group from $1765 \mathrm{~cm}^{-1}$ to $1731 \mathrm{~cm}^{-1}$ indicated the presence of the ester. In the ${ }^{1} \mathrm{H}$-NMR spectra of the new HBA esters, the signal at 5.0-6.0 $(\mathrm{s}, 1 \mathrm{H})$ disappeared, indicating that the hydroxyl was esterified; the signal at 9.0-9.5 (s, 1H) disappeared, suggesting that the phenolic hydroxyl was esterified. In the ${ }^{13} \mathrm{C}-\mathrm{NMR}$ spectra of all HBA esters, the presence of signals at 165.0$175.0 \mathrm{ppm}$ suggests the introduction of ester bonds. By comparing the IR, ${ }^{1} \mathrm{H}-\mathrm{NMR},{ }^{13} \mathrm{C}-\mathrm{NMR}$ and HRMS spectra, it was shown that the esterification reaction was successful. In all, we got 4-hydroxybenzyl alcohol 3-furoate (FHBA), 4-hydroxybenzyl alcohol 3-furancarboxylic acid diester (2FHBA), 4-hydroxybenzyl alcohol 2-naphthoate (NHBA), 4-hydroxybenzyl alcohol 2naphthoic acid diester (2NHBA), 4-hydroxybenzyl alcohol benzoate (BHBA), 4-hydroxybenzyl alcohol benzoic acid diester (2BHBA), 4-hydroxybenzyl alcohol oleic acid diester (OHBA), 4hydroxybenzyl alcohol linoleic acid diester (LoHBA), 4-hydroxybenzyl alcohol sorbic acid diester (SHBA), and 4-hydroxybenzyl alcohol lauric acid diester (LHBA).

3.1.1. 4-Hydroxybenzyl alcohol 3-furancarboxylic acid diester (2FHBA). Yield: 51.72\%, white powder, melting point: 233-234 ${ }^{\circ} \mathrm{C}$, HRMS (ESI) calcd for $[\mathrm{M}+\mathrm{H}]^{+} \mathrm{C}_{17} \mathrm{H}_{12} \mathrm{O}_{6}{ }^{+}$: 312.0634, found: 312.0639 . IR spectrum: the peak at $3148 \mathrm{~cm}^{-1}$ is the stretching vibration peak of $\mathrm{Ar}_{\mathrm{C}-\mathrm{H}}$; that at $2980 \mathrm{~cm}^{-1}$ is the hydrocarbon stretching vibration peak $\left(\nu_{\mathrm{C}-\mathrm{H}}\right)$ of $\mathrm{CH}_{2}$. The elongation vibration peak $\left(\nu_{\mathrm{C}=\mathrm{O}}\right)$ of the carbonyl group is shown at $1734 \mathrm{~cm}^{-1}$, suggesting the presence of the ester. The peak at $1685 \mathrm{~cm}^{-1}$ is the stretching vibration peak $\left(\nu_{\mathrm{C}=\mathrm{C}}\right)$ of $\mathrm{C}=\mathrm{C}$. The peaks at $1607 \mathrm{~cm}^{-1}, 1575 \mathrm{~cm}^{-1}, 1507 \mathrm{~cm}^{-1}$, and $1464 \mathrm{~cm}^{-1}$ are the characteristic absorption peaks of the benzene ring.

${ }^{1} \mathrm{H}-\mathrm{NMR}\left(300 \mathrm{MHz}, \mathrm{CDCl}_{3}\right.$ ) $\delta \mathrm{ppm}: 8.199$ (s, 1H, 17-H), 8.047 (s, 1H, 12-H), 7.509 (t, 1H, $J=1.5 \mathrm{~Hz}, 16-\mathrm{H}), 7.478(\mathrm{dt}, 1 \mathrm{H}, J=$ 8.4, $2.7 \mathrm{~Hz}, 15-\mathrm{H}), 7.431$ (t, $2 \mathrm{H}, 3,5-\mathrm{H}), 7.212$ (t, $1 \mathrm{H}, J=2.7 \mathrm{~Hz}$,

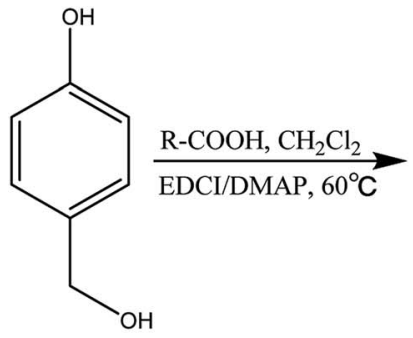<smiles>CCOc1ccc(CO)cc1</smiles>

Monoester $\mathrm{R}_{1}=$ furan-3-carbonyl $\mathrm{R}_{1}=$ benzoyl $\mathrm{R}_{1}=$ 2-naphthoyl
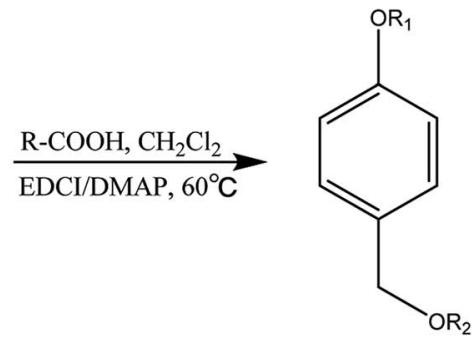

Diester

$\mathrm{R}_{1}, \mathrm{R}_{2}=$ furan-3-carbonyl

$\mathrm{R}_{1}, \mathrm{R}_{2}=$ benzoyl

$\mathrm{R}_{1}, \mathrm{R}_{2}=$ 2-naphthoyl

$\mathrm{R}_{1}, \mathrm{R}_{2}=$ octadecadienoyl

$\mathrm{R}_{1}, \mathrm{R}_{2}=$ (z)-9-octadecanoyl

$\mathrm{R}_{1}, \mathrm{R}_{2}=$ dodecanoyl

$\mathrm{R}_{1}, \mathrm{R}_{2}=2,4$-hexadienoyl

Fig. 1 Compounds of the synthesis process and substituents. 
$10-\mathrm{H}), 7.189(\mathrm{t}, 1 \mathrm{H}, J=1.8 \mathrm{~Hz}, 11-\mathrm{H}), 6.876(\mathrm{~d}, 1 \mathrm{H}, J=1.8 \mathrm{~Hz}, 2-$ H), $6.773(\mathrm{~d}, 1 \mathrm{H}, J=2.1 \mathrm{~Hz}, 6-\mathrm{H}), 5.297$ (s, 2H, 7-H), 1.607-0.075 (others); ${ }^{13} \mathrm{C}-\mathrm{NMR}\left(75 \mathrm{MHz}, \mathrm{CDCl}_{3}\right.$ ) $\delta \mathrm{ppm:} 162.774$ (C8), 161.204 (C13), 150.275 (C16), 148.699 (C11), 147.882 (C4), 144.057 (C17), 143.755 (C12), 133.613 (C1), 129.469 (C2, C6), 121.815 (C3, C5), 119.131 (C14), 118.681 (C9), 109.973 (C15), 109.784 (C10), 65.459 (C7).

3.1.2. 4-Hydroxybenzyl alcohol 3-furoate (FHBA). Yield: $47.65 \%$, white powder, melting point: $145-146{ }^{\circ} \mathrm{C}$, HRMS (ESI) calcd for $[\mathrm{M}+\mathrm{H}]^{+} \mathrm{C}_{12} \mathrm{H}_{10} \mathrm{O}_{4}^{+}$: 218.0579, found: 218.0585. IR spectra: the peak at $3462 \mathrm{~cm}^{-1}$ is the stretching vibration peak $\left(\nu_{\mathrm{OH}}\right)$ of the hydroxyl group; that at $3047 \mathrm{~cm}^{-1}$ is the hydrocarbon stretching vibration peak $\left(\nu_{\mathrm{Ar}_{\mathrm{CH}}}\right)$ of the benzene ring. The peak at $2884 \mathrm{~cm}^{-1}$ is the hydrocarbon stretching vibration peak $\left(\nu_{\mathrm{C}-\mathrm{H}}\right)$ of $\mathrm{CH}_{2}$. The telescopic vibration peak $\left(\nu_{\mathrm{C}=\mathrm{O}}\right)$ of the carbonyl group is at $1733 \mathrm{~cm}^{-1}$. The peak at $1651 \mathrm{~cm}^{-1}$ is the stretching vibration peak $\left(\nu_{\mathrm{C}=\mathrm{C}}\right)$ of olefin. The peaks at $1603 \mathrm{~cm}^{-1}, 1507 \mathrm{~cm}^{-1}$, and $1455 \mathrm{~cm}^{-1}$ are the characteristic absorption peaks of the benzene ring.

${ }^{1} \mathrm{H}-\mathrm{NMR}\left(300 \mathrm{MHz}, \mathrm{CDCl}_{3}\right.$ ) $\delta$ ppm: $8.199(\mathrm{~m}, 1 \mathrm{H}, 12-\mathrm{H}), 7.506$ (t, $1 \mathrm{H}, J=1.8 \mathrm{~Hz}, 11-\mathrm{H}), 7.429(\mathrm{dt}, 1 \mathrm{H}, J=8.7,2.1 \mathrm{~Hz}, 10-\mathrm{H})$, 7.191 (dt, $2 \mathrm{H}, J=8.4,2.4 \mathrm{~Hz}, 3,5-\mathrm{H}), 6.875$ (dd, $2 \mathrm{H}, J=1.8$, $0.9 \mathrm{~Hz}, 2,6-\mathrm{H}), 5.292$ (s, 1H, 7-OH), 4.698 (s, 2H, 7-H); ${ }^{13} \mathrm{C}-\mathrm{NMR}$ (75 $\mathrm{MHz}, \mathrm{CDCl}_{3}$ ) $\delta$ ppm: 161.461 (C8), 149.551 (C11), 147.881 (C4), 143.983 (C12), 138.644 (C1), 129.417 (C2, C6), 127.942 (C3, C5), 121.572 (C9), 109.906 (C10), 64.373 (C7).

3.1.3. 4-Hydroxybenzyl alcohol linoleic acid diester (LoHBA). Yield: 87.61\%, light yellow oily liquid, HRMS (ESI) calcd for $[\mathrm{M}+\mathrm{H}]^{+} \mathrm{C}_{43} \mathrm{H}_{68} \mathrm{O}_{4}{ }^{+}$: 648.5118, found: 648.5126. IR spectra: the peak at $3022 \mathrm{~cm}^{-1}$ is the hydrocarbon stretching vibration peak $\left(\nu_{\mathrm{Ar}_{\mathrm{C}-\mathrm{H}}}\right)$ of the benzene ring. The peak at $2940 \mathrm{~cm}^{-1}$ is the stretching vibration peak $\left(\nu_{\text {as }} \mathrm{C}-\mathrm{H}\right)$ of $\mathrm{CH}_{2}$. The peak at $2867 \mathrm{~cm}^{-1}$ is the hydrocarbon stretching vibration peak $\left(\nu_{\mathrm{s}-\mathrm{H}}\right)$ of $\mathrm{CH}_{2}$. The peaks at $1765 \mathrm{~cm}^{-1}$ and $1746 \mathrm{~cm}^{-1}$ are telescopic vibration peaks $\left(\nu_{\mathrm{C}=\mathrm{O}}\right)$ of the carbonyl group; those at $1611 \mathrm{~cm}^{-1}, 1513 \mathrm{~cm}^{-1}$, and $1458 \mathrm{~cm}^{-1}$ are the telescopic vibration peaks of the benzene ring. The peaks at $1383 \mathrm{~cm}^{-1}$ and $1353 \mathrm{~cm}^{-1}$ are the deformation vibration peaks of the methyl group $\left(\delta_{\mathrm{CH}_{3}}\right)$.

${ }^{1} \mathrm{H}-\mathrm{NMR}\left(300 \mathrm{MHz}, \mathrm{CDCl}_{3}\right) \delta$ ppm: $7.374(\mathrm{~d}, 2 \mathrm{H}, J=8.4 \mathrm{~Hz}, 3$, 5-H), 7.079 (d, 2H, $J=8.4 \mathrm{~Hz}, 2,6-\mathrm{H}), 5.352(\mathrm{~m}, 8 \mathrm{H}, 37,35,20$, 19, 34, 38, 16, 17-H), 5.091 (s, 2H, 7-H), $2.794(\mathrm{t}, 4 \mathrm{H}, J=5.7 \mathrm{~Hz}$, 18, 35-H), $2.753(\mathrm{t}, 2 \mathrm{H}, J=7.5 \mathrm{~Hz}, 27-\mathrm{H}), 2.364(\mathrm{t}, 2 \mathrm{H}, J=7.5 \mathrm{~Hz}$, 9-H), $2.058(\mathrm{t}, 8 \mathrm{H}, J=6.6 \mathrm{~Hz}, 15,21,33,39-\mathrm{H}), 1.773(\mathrm{~m}, 4 \mathrm{H}, 10$, 28-H), 1.301 (m, 24H, 11, 29, 13, 31, 14, 32, 22, 40, 23, 41, 24, 42$\mathrm{H}), 0.888(\mathrm{~m}, 6 \mathrm{H}, 25,43-\mathrm{H}) ;{ }^{13} \mathrm{C}-\mathrm{NMR}\left(75 \mathrm{MHz}, \mathrm{CDCl}_{3}\right) \delta \mathrm{ppm}$ : 173.441 (C8), 172.032 (C26), 150.529 (C4), 133.566 (C1), 130.120 (C16, C20), 129.952 (C34), 129.902 (C38), 129.323 (C2, C6), 128.031 (C17), 127.977 (C19), 127.847 (C35, C37), 121.619 (C3, C5), 65.327 (C7), 34.301 (C36), 34.221 (C9), 31.864 (C33), 31.477 (C39), 29.720 (C27), 29.629 (C23, C41), 29.536 (C14, C32), 29.479 (C13), 29.414 (C31), 29.276 (C22), 29.203 (C40), 29.102 (C12, C30), 29.039 (C11, C29), 27.155 (C15, C21), 25.588 (C18), 24.856 (C10, C28), 22.640 (C24), 22.529 (C42), 14.059 (C25), 14.019 (C43).

3.1.4. 4-Hydroxybenzyl alcohol lauric acid diester (LHBA). Yield: $91.33 \%$, white powder, melting point: $280-281^{\circ} \mathrm{C}$, HRMS
(ESI) calcd for $[\mathrm{M}+\mathrm{H}]^{+} \mathrm{C}_{31} \mathrm{H}_{52} \mathrm{O}_{4}{ }^{+}$: 488.3866, found: 488.3872 . IR spectra: the peak at $2968 \mathrm{~cm}^{-1}$ is the stretching vibration peak $\left(\nu_{\text {as C-H }}\right)$ of $\mathrm{CH}_{3}$. The peak at $2932 \mathrm{~cm}^{-1}$ is the stretching vibration peak $\left(\nu_{\text {as } \mathrm{C}-\mathrm{H}}\right)$ of $\mathrm{CH}_{2}$, and that at $2860 \mathrm{~cm}^{-1}$ is the stretching vibration peak $\left(\nu_{\mathrm{S}} \mathrm{C}-\mathrm{H}\right)$ of $\mathrm{CH}_{2}$. The telescopic vibration peaks $\left(\nu_{\mathrm{C}=\mathrm{O}}\right)$ of the carbonyl group are at $1761 \mathrm{~cm}^{-1}$ and $1740 \mathrm{~cm}^{-1}$. The peaks at $1602 \mathrm{~cm}^{-1}, 1554 \mathrm{~cm}^{-1}, 1506 \mathrm{~cm}^{-1}$ and $1467 \mathrm{~cm}^{-1}$ are the telescopic vibration peaks of the benzene ring. The peak at $1383 \mathrm{~cm}^{-1}$ is the deformation vibration peak of methyl group $\left(\delta_{\mathrm{CH}_{3}}\right)$.

${ }^{1} \mathrm{H}-\mathrm{NMR}\left(300 \mathrm{MHz}, \mathrm{CDCl}_{3}\right.$ ) $\delta$ ppm: $7.374(\mathrm{~d}, 2 \mathrm{H}, J=8.4 \mathrm{~Hz}, 3$, 5-H), $7.079(\mathrm{~d}, 2 \mathrm{H}, J=8.4 \mathrm{~Hz}, 2,6-\mathrm{H}), 5.091(\mathrm{~s}, 2 \mathrm{H}, 7-\mathrm{H}), 2.572(\mathrm{t}$, $2 \mathrm{H}, J=7.5 \mathrm{~Hz}, 21-\mathrm{H}), 2.363$ (t, 2H, $J=7.5 \mathrm{~Hz}, 9-\mathrm{H}), 1.771(\mathrm{~m}, 4 \mathrm{H}$, 10, 22-H), 1.251 (s, 32H, 11, 12, 13, 14, 15, 16, 17, 18, 23, 24, 25, 26, 27, 28, 29, 30-H), 0.899 (t, 6H, $J=6.3 \mathrm{~Hz}, 19,31-\mathrm{H}) ;{ }^{13} \mathrm{C}-\mathrm{NMR}$ (75 MHz, $\mathrm{CDCl}_{3}$ ) $\delta$ ppm: 173.463 (C8), 172.065 (C20), 150.459 (C4), 133.497 (C1), 129.258 (C2, C6), 121.562 (C3, C5), 65.266 (C7), 34.257 (C9), 34.182 (C21), 31.788 (C17, C29), 29.475 (C13, C25), 29.330 (C14, C26), 29.211 (C15, C27), 29.127 (C12, C24), 29.007 (C16, C28), 28.979 (C11, C23), 24.807 (C10, C22), 22.562 (C18, C30), 13.981 (C19, C31).

3.1.5. 4-Hydroxybenzyl alcohol sorbic acid diester (SHBA). Yield: $82.38 \%$, light yellow solid, melting point: $132-133{ }^{\circ} \mathrm{C}$, HRMS (ESI) calcd for $[\mathrm{M}+\mathrm{H}]^{+} \mathrm{C}_{19} \mathrm{H}_{20} \mathrm{O}_{4}{ }^{+}$: 312.1362, found: 312.1369. IR spectra: the peak at $3047 \mathrm{~cm}^{-1}$ is the hydrocarbon stretching vibration peak $\left(\nu_{\mathrm{Ar}_{\mathrm{C}-\mathrm{H}}}\right)$ of the benzene ring. The peak at $2983 \mathrm{~cm}^{-1}$ is the stretching vibration peak $\left(\nu_{\mathrm{C}-\mathrm{H}}\right)$ of $\mathrm{CH}_{2}$. The peak at $2875 \mathrm{~cm}^{-1}$ is the stretching vibration peak $\left(\nu_{\mathrm{C}-\mathrm{H}}\right)$ of the $\mathrm{CH}_{3}$; those at $1761 \mathrm{~cm}^{-1}$ and $1740 \mathrm{~cm}^{-1}$ are the stretching vibration peaks $\left(\nu_{\mathrm{C}=\mathrm{O}}\right)$ of the carbonyl group; and that at $1647 \mathrm{~cm}^{-1}$ is $\nu_{\mathrm{C}=\mathrm{C}}$, indicating the presence of olefin. The peaks at $1610 \mathrm{~cm}^{-1}, 1509 \mathrm{~cm}^{-1}$, and $1450 \mathrm{~cm}^{-1}$ are the telescopic vibration peaks of the benzene ring.

${ }^{1} \mathrm{H}-\mathrm{NMR}\left(300 \mathrm{MHz}, \mathrm{CDCl}_{3}\right.$ ) $\delta \mathrm{ppm}: 7.409(\mathrm{~d}, 2 \mathrm{H}, J=8.4 \mathrm{~Hz}$, 10, 16-H), 7.260 (m, 2H, 3, 5-H), 7.132 (d, 2H, $=8.4 \mathrm{~Hz}, 2,6-\mathrm{H})$, 6.279 (m, 2H, 11, 17-H), 5.983 (d, $2 \mathrm{H}, J=15.3 \mathrm{~Hz}, 12,18-\mathrm{H})$, 5.835 (d, 2H, J=15.6 Hz, 9, 15-H), 5.170 (s, 2H, 7-H), 1.906 (dd, $6 \mathrm{H}, J=5.1,6.9 \mathrm{~Hz}, 13,19-\mathrm{H}) ;{ }^{13} \mathrm{C}-\mathrm{NMR}\left(75 \mathrm{MHz} \mathrm{CDCl}_{3}\right) \delta \mathrm{ppm}$ : 166.835 (C14), 165.349 (C8), 150.589 (C4), 146.826 (C16), 145.358 (C10), 140.489 (C12), 139.406 (C18), 133.503 (C1), 129.651 (C11), 129.621 (C17), 129.197 (C2, C6), 121.587 (C3, C5), 118.482 (C9), 117.833 (C15), 65.273 (C7), 18.515 (C13), 18.413 (C19).

3.1.6. 4-Hydroxybenzyl alcohol benzoic acid diester (2BHBA). Yield: $56.15 \%$, white powder, melting point: $225-$ $226{ }^{\circ} \mathrm{C}$, HRMS (ESI) calcd for $[\mathrm{M}+\mathrm{H}]^{+} \mathrm{C}_{21} \mathrm{H}_{16} \mathrm{O}_{4}{ }^{+}$: 332.1048, found: 332.1057 . IR spectra: the peak at $3076 \mathrm{~cm}^{-1}$ is the telescopic vibration peak of $\mathrm{Ar}_{\mathrm{C}-\mathrm{H}}$, and the peak at $2974 \mathrm{~cm}^{-1}$ is the telescopic vibration peak $\left(\nu_{\mathrm{C}-\mathrm{H}}\right)$ of the $\mathrm{CH}_{2}$. The telescopic vibration peaks $\left(\nu_{\mathrm{C}=\mathrm{O}}\right)$ of the carbonyl group are at $1737 \mathrm{~cm}^{-1}$ and $1710 \mathrm{~cm}^{-1}$. The peaks at $1602 \mathrm{~cm}^{-1}, 1507 \mathrm{~cm}^{-1}, 1496 \mathrm{~cm}^{-1}$, and $1455 \mathrm{~cm}^{-1}$ are the telescopic vibration peaks of the benzene ring.

${ }^{1} \mathrm{H}-\mathrm{NMR}\left(300 \mathrm{MHz}, \mathrm{CDCl}_{3}\right) \delta \mathrm{ppm}: 8.223(\mathrm{dt}, 2 \mathrm{H}, J=6.9$, $3.0 \mathrm{~Hz}, 17,21-\mathrm{H}), 8.102(\mathrm{dt}, 2 \mathrm{H}, J=6.9,3.0 \mathrm{~Hz}, 10,14-\mathrm{H}), 7.671$ (m, 6H, 19, 12, 18, 20, 11, 13-H), 7.260 (d, 2H, J = 2.1 Hz, 3, 5-H), 7.238 (d, 2H, $=1.8 \mathrm{~Hz}, 2,6-\mathrm{H}), 5.384$ (s, 2H, 7-H); ${ }^{13} \mathrm{C}-\mathrm{NMR}$ (75 
$\mathrm{MHz}, \mathrm{CDCl}_{3}$ ) $\delta$ ppm: 166.197 (C8), 164.922 (C15), 150.729 (C4), 133.602 (C19), 133.526 (C12), 132.949 (C1), 130.039 (C17, C21), 129.904 (C16), 129.567 (C9), 129.364 (C10, C14), 129.277 (C2, C6), 128.454 (C11, C13), 128.267 (C18, C20), 121.789 (C3, C5), $65.924(\mathrm{C} 7)$.

3.1.7. 4-Hydroxybenzyl alcohol benzoate (BHBA). Yield: $35.17 \%$, colorless flaky crystals, melting point: $139-140{ }^{\circ} \mathrm{C}$, HRMS (ESI) calcd for $[\mathrm{M}+\mathrm{H}]^{+} \mathrm{C}_{14} \mathrm{H}_{12} \mathrm{O}_{3}{ }^{+}$: 228.0786, found: 228.0793. IR spectra: the peak at $3508-3102 \mathrm{~cm}^{-1}$ is the stretching vibration peak $\left(\nu_{\mathrm{OH}}\right)$ of the hydroxyl group; that at $3052 \mathrm{~cm}^{-1}$ is the telescopic vibration peak $\left(\nu_{\mathrm{Ar}_{\mathrm{C}-\mathrm{H}}}\right)$ of benzene. The peak at $2932 \mathrm{~cm}^{-1}$ is the stretching vibration peak $\left(\nu_{\mathrm{C}-\mathrm{H}}\right)$ of the $\mathrm{CH}_{2}$. The telescopic vibration peak $\left(\nu_{\mathrm{C}=\mathrm{O}}\right)$ of the carbonyl group is $1737 \mathrm{~cm}^{-1}$; the peaks at $1602 \mathrm{~cm}^{-1}, 1587 \mathrm{~cm}^{-1}$, $1507 \mathrm{~cm}^{-1}$ and $1455 \mathrm{~cm}^{-1}$ are the telescopic vibration peaks of the benzene ring.

${ }^{1} \mathrm{H}-\mathrm{NMR}\left(300 \mathrm{MHz}, \mathrm{CDCl}_{3}\right) \delta \mathrm{ppm}: 8.219(\mathrm{dt}, 2 \mathrm{H}, J=7.2$, $1.2 \mathrm{~Hz}, 10,14-\mathrm{H}), 7.669$ (m, 3H, 12, 11, 13-H), 7.447 (dt, 2H, $J=$ 7.8, $2.1 \mathrm{~Hz}, 3,5-\mathrm{H}), 7.254(\mathrm{~s}, 1 \mathrm{H}, 7-\mathrm{OH}), 7.228$ (dt, $2 \mathrm{H}, J=8.4$, $2.7 \mathrm{~Hz}, 2,6-\mathrm{H}), 4.706$ (s, 2H, 7-H); ${ }^{13} \mathrm{C}-\mathrm{NMR}$ (75 MHz, $\mathrm{CDCl}_{3}$ ) $\delta$ ppm: 165.085 (C8), 150.162 (C4), 138.399 (C1), 133.452 (C12), 130.001 (C10, C14, C9), 128.399 (C2, C6), 127.948 (C11, C13), 121.629 (C3, C5), 64.581 (C7).

3.1.8. 4-Hydroxybenzyl alcohol 2-naphthoic acid diester (2NHBA). Yield: 58.23\%, white powder, melting point: 407$408{ }^{\circ} \mathrm{C}$, HRMS (ESI) calcd for $[\mathrm{M}+\mathrm{H}]^{+} \mathrm{C}_{29} \mathrm{H}_{20} \mathrm{O}_{4}{ }^{+}:$432.1362, found: 432.1366 . IR spectra: the peak at $3074 \mathrm{~cm}^{-1}$ is the telescopic vibration peak $\left(\nu_{\mathrm{Ar}_{\mathrm{C}-\mathrm{H}}}\right)$ of benzene. The peak at $2952 \mathrm{~cm}^{-1}$ is the stretching vibration peak $\left(\nu_{\mathrm{C}-\mathrm{H}}\right)$ of the $\mathrm{CH}_{2}$. The peaks at $1740 \mathrm{~cm}^{-1}$ and $1731 \mathrm{~cm}^{-1}$ are the stretching vibration peaks $\left(\nu_{\mathrm{C}=\mathrm{O}}\right)$ of the carbonyl group. The peaks at $1601 \mathrm{~cm}^{-1}$, $1560 \mathrm{~cm}^{-1}, 1509 \mathrm{~cm}^{-1}$, and $1466 \mathrm{~cm}^{-1}$ are the telescopic vibration peaks of the benzene ring.

${ }^{1} \mathrm{H}-\mathrm{NMR}\left(300 \mathrm{MHz}, \mathrm{CDCl}_{3}\right.$ ) $\delta \mathrm{ppm}: 8.793$ (s, 1H, 25-H), 8.657 (s, 1H, 10-H), 8.215 (m, 6H, 20, 19, 16, 21, 15, 24-H), 8.124 (dd, $2 \mathrm{H}, J=1.8,6.9 \mathrm{~Hz}, 11,14-\mathrm{H}), 8.019$ (m, 2H, 22, 23-H), 7.661 (m, $2 \mathrm{H}, 12,13-\mathrm{H}), 7.336$ (d, 2H, $J=2.1 \mathrm{~Hz}, 3,5-\mathrm{H}), 7.314$ (d, 2H, $J=$ $1.8 \mathrm{~Hz}, 2,6-\mathrm{H}), 5.460$ (s, 2H, 7-H); ${ }^{13} \mathrm{C}-\mathrm{NMR}$ (75 MHz, $\mathrm{CDCl}_{3}$ ) $\delta$ ppm: 166.466 (C8), 165.196 (C17), 150.921 (C4), 135.756 (C14-
15), 135.513 (C20-21), 133.711 (C1, C10-11, C24-25), 132.401 (C10, C25), 131.909 (C11), 131.174 (C24), 129.565 (C2, C6), 129.409 (C18), 129.313 (C13), 128.598 (C22), 128.348 (C15), 128.238 (C20), 128.138 (C9), 127.758 (C14), 127.689 (C21), 126.787 (C12), 126.594 (C23), 125.346 (C16), 125.201 (C19), 121.948 (C3, C5), 66.179 (C7).

3.1.9. 4-Hydroxybenzyl alcohol 2-naphthoate (NHBA). Yield: $38.11 \%$, white flaky crystals, melting point: $242-243{ }^{\circ} \mathrm{C}$, HRMS (ESI) calcd for $[\mathrm{M}+\mathrm{H}]^{+} \mathrm{C}_{18} \mathrm{H}_{14} \mathrm{O}_{3}{ }^{+}$: 278.0943, found: 278.0949. IR spectra: the peak at $3394 \mathrm{~cm}^{-1}$ is the stretching vibration peak $\left(\nu_{\mathrm{OH}}\right)$ of the hydroxyl group; that at $3070 \mathrm{~cm}^{-1}$ is the stretching vibration peak of $\mathrm{Ar}_{\mathrm{C}-\mathrm{H}}$. The peak at $2878 \mathrm{~cm}^{-1}$ is the stretching vibration peak $\left(\nu_{\mathrm{C}-\mathrm{H}}\right)$ of the $\mathrm{CH}_{2}$. The telescopic vibration peak $\left(\nu_{\mathrm{C}=\mathrm{O}}\right)$ of the carbonyl group is at $1737 \mathrm{~cm}^{-1}$. The peaks at $1601 \mathrm{~cm}^{-1}, 1507 \mathrm{~cm}^{-1}$, and $1466 \mathrm{~cm}^{-1}$ are the telescopic vibration peaks of the benzene ring.

${ }^{1} \mathrm{H}-\mathrm{NMR}\left(300 \mathrm{MHz}, \mathrm{CDCl}_{3}\right.$ ) $\delta \mathrm{ppm}: 8.783(\mathrm{~s}, 1 \mathrm{H}, 10-\mathrm{H}), 8.206$ (d, $2 \mathrm{H}, J=1.8 \mathrm{~Hz}, 15,16-\mathrm{H}), 8.177$ (d, $2 \mathrm{H}, J=1.8 \mathrm{~Hz}, 14,11-\mathrm{H})$, $8.011(\mathrm{~m}, 2 \mathrm{H}, 12,13-\mathrm{H}), 7.470(\mathrm{dt}, 2 \mathrm{H}, J=8.7,2.4 \mathrm{~Hz}, 3,5-\mathrm{H})$, $7.281(\mathrm{dt}, 2 \mathrm{H}, J=8.7,2.4 \mathrm{~Hz}, 2,6-\mathrm{H}), 4.721(\mathrm{~s}, 2 \mathrm{H}, 7-\mathrm{H}) ;{ }^{13} \mathrm{C}-\mathrm{NMR}$ (75 MHz, $\mathrm{CDCl}_{3}$ ) $\delta$ ppm: 165.325 (C8), 150.324 (C4), 138.495 (C1), 135.722 (C14-15), 132.386 (C10-11), 131.841 (C10), 129.377 (C11), 128.541 (13), 128.296 (C2, C6), 128.048 (C9), 127.726 (C15), 126.742 (C14), 126.556 (C12), 125.326 (C16), 121.755 (C3, C5), 64.669 (C7).

3.1.10. 4-Hydroxybenzyl alcohol oleic acid diester (OHBA). Yield: 93.04\%, light yellow oily liquid, HRMS (ESI) calcd for [M + $\mathrm{H}]^{+} \mathrm{C}_{43} \mathrm{H}_{72} \mathrm{O}_{4}{ }^{+}$: 652.5431, found: 652.5437. IR spectra: the peak at $3070 \mathrm{~cm}^{-1}$ is the stretching vibration peak $\left(\nu_{\mathrm{Ar}_{\mathrm{C}-\mathrm{H}}}\right)$ of the benzene. The peak at $2860 \mathrm{~cm}^{-1}$ is the stretching vibration peak $\left(\nu_{\mathrm{C}-\mathrm{H}}\right)$ of $\mathrm{CH}_{2}$. The telescopic vibration peaks $\left(\nu_{\mathrm{C}=\mathrm{O}}\right)$ of the carbonyl group are at $1763 \mathrm{~cm}^{-1}$ and $1743 \mathrm{~cm}^{-1}$. The peaks at $1605 \mathrm{~cm}^{-1}, 1505 \mathrm{~cm}^{-1}$, and $1467 \mathrm{~cm}^{-1}$ are the telescopic vibration peaks of the benzene ring. The peak at $1380 \mathrm{~cm}^{-1}$ is the deformation vibration peak of the methyl group $\left(\delta_{\mathrm{CH}_{3}}\right)$.

${ }^{1} \mathrm{H}-\mathrm{NMR}\left(300 \mathrm{MHz}, \mathrm{CDCl}_{3}\right) \delta \mathrm{ppm}: 7.374(\mathrm{dt}, 2 \mathrm{H}, J=8.4$, $2.7 \mathrm{~Hz}, 3,5-\mathrm{H}), 7.078$ (dt, $1 \mathrm{H}, J=8.7,2.7 \mathrm{~Hz}, 2,6-\mathrm{H}), 5.359$ (m, $4 \mathrm{H}, 16,17,34,35-\mathrm{H}), 5.09(\mathrm{~s}, 2 \mathrm{H}, 7-\mathrm{H}), 2.547$ (t, $2 \mathrm{H}, J=7.2 \mathrm{~Hz}$, 27-H), 2.339 (t, 2H, J = 7.5 Hz, 9-H), 2.034 (m, 8H, 15, 18, 33, 36-

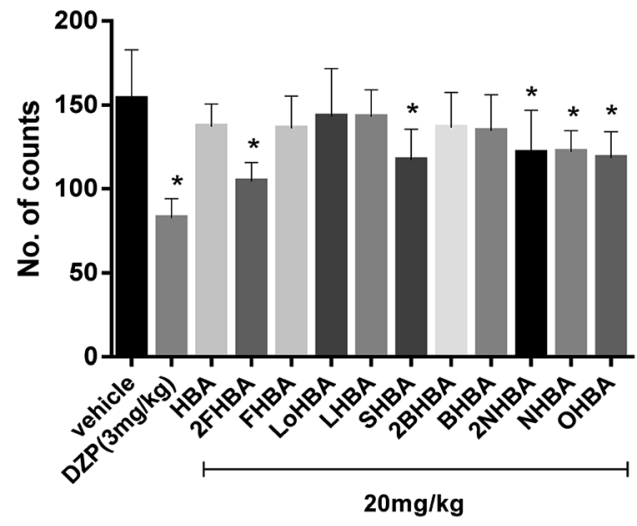

A

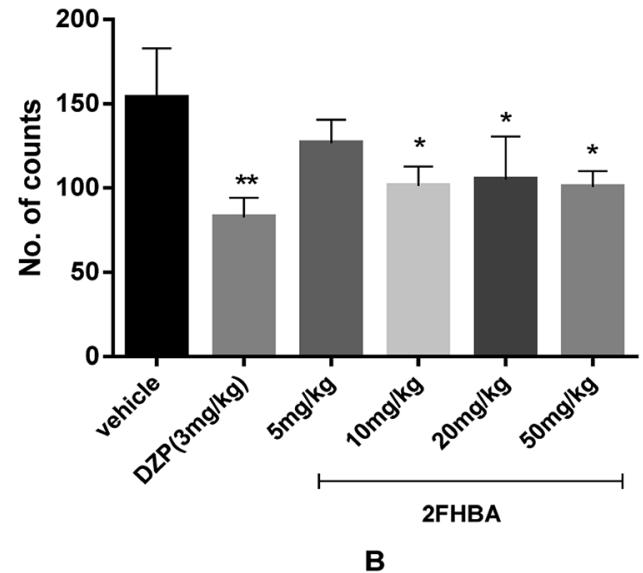

Fig. 2 The sedative effect of HBA esters on spontaneous locomotor activity (A); the sedative effect of different doses of $2 \mathrm{FHBA}$ on spontaneous locomotor activity (B) (10 in each group). ${ }^{*} p<0.05$ and ${ }^{* *} p<0.01$ compared with the vehicle group. 
$\mathrm{H}), 1.748$ (m, 4H, 10, 28-H), 1.300 (m, 40H, 11, 29, 13, 31, 20, 38, $21,39,14,32,19,37,12,30,22,23,24,40,41,42-\mathrm{H}), 0.888$ (m, 6H, 25, 43-H); ${ }^{13} \mathrm{C}-\mathrm{NMR}$ (75 MHz, $\mathrm{CDCl}_{3}$ ) $\delta$ ppm: 173.497 (C8), 172.093 (C26), 150.518 (C4), 133.555 (C1), 129.969 (C16), 129.916 (C17), 129.679 (C34), 129.634 (C35), 129.332 (C2, C6), 121.625 (C3, C5), 65.343 (C7), 34.313 (C9, C15, C18), 34.234 (C27, C33, C36), 31.853 (C23, C41), 29.714 (C14, C19, C32, C37), 29.625 (C20, C21, C38, C39), 29.529 (C13, C31), 29.469 (C12, C30), 29.268 (C22, C40), 29.035 (C11, C29), 25.578 (C10), 25.479 (C28), 22.629 (C24), 22.519 (C42), 14.057 (C25), 14.017 (C43).

\subsection{Spontaneous locomotor activity test (SLT)}

Spontaneous motor activity is usually considered as an effective index of alertness or a decrease in motor activity that leads to sedation, ${ }^{34}$ as a result of the reduced excitability of the central nervous system. Therefore, the spontaneous locomotor activities of mice treated with the newly synthesized HBA esters were

Table 1 The effect of HBA esters on the sleep onset of mice treated with a sub-hypnotic dose of pentobarbital $\left(28 \mathrm{mg} \mathrm{kg}^{-1}\right)^{a}$

\begin{tabular}{llll}
\hline Group & $\begin{array}{l}\text { Dosage } \\
\left(\mathrm{mg} \mathrm{kg}^{-1}, \text { i.g. }\right)\end{array}$ & $\begin{array}{l}\text { No. falling } \\
\text { asleep/total }\end{array}$ & $\begin{array}{l}\text { Sleep } \\
\text { onset (\%) }\end{array}$ \\
\hline Vehicle & - & $1 / 10$ & 10 \\
DZP & 3 & $10 / 10$ & $100^{\# \#}$ \\
HBA & 20 & $1 / 10$ & 10 \\
2FHBA & 20 & $9 / 10$ & $90^{\# \#}$ \\
FHBA & 20 & $1 / 10$ & 10 \\
LoHBA & 20 & $1 / 10$ & 10 \\
LHBA & 20 & $1 / 10$ & 10 \\
SHBA & 20 & $1 / 10$ & 10 \\
$2 B H B A$ & 20 & $0 / 10$ & 0 \\
BHBA & 20 & $0 / 10$ & 0 \\
2 NHBA & 20 & $2 / 10$ & 20 \\
NHBA & 20 & $0 / 10$ & 0 \\
OHBA & 20 & $0 / 10$ & 0
\end{tabular}

${ }^{a}$ Statistical analysis by chi-square test (the $\chi^{2}$ test); ${ }^{\# \#} p<0.01$ compared with the vehicle group. detected using a ZZ-6 locomotor activity tester to determine their sedative effects. The number of autonomous activities was recorded after oral administration of the different HBA esters $\left(20 \mathrm{mg} \mathrm{kg}^{-1}\right)$ and diazepam $\left(3 \mathrm{mg} \mathrm{kg}^{-1}\right)$. Fig. 2A shows that the 2FHBA, SHBA, 2NHBA, NHBA, and OHBA groups displayed obvious sedative effects compared with the vehicle group $(p<$ 0.05). However, 2FHBA (20 mg kg ${ }^{-1}$ ) exhibited the strongest sedative activity. Therefore, a series of dosages $\left(5 \mathrm{mg} \mathrm{kg} \mathrm{kg}^{-1}\right.$, $10 \mathrm{mg} \mathrm{kg}^{-1}$, $20 \mathrm{mg} \mathrm{kg}^{-1}$ and $50 \mathrm{mg} \mathrm{kg}^{-1}$ ) of 2FHBA were investigated, and the results (Fig. 2B) demonstrated that $10 \mathrm{mg}$ $\mathrm{kg}^{-1}$ of $2 \mathrm{FHBA}$ showed the best sedative effect, and the subsedative dose was $5 \mathrm{mg} \mathrm{kg}^{-1}$.

\subsection{Screening of the HBA derivatives for hypnotic activity}

Sodium pentobarbital ( $28 \mathrm{mg} \mathrm{kg}^{-1}$ or $42 \mathrm{mg} \mathrm{kg}^{-1}$ ) was used to record the falling asleep rate, sleep latency and sleep duration time. As we can see from Table 1, DZP, the positive control, showed the strongest hypnotic activity, in which the ratio of mice falling asleep was $100 \%(p<0.01)$. Meanwhile, the 2FHBA group administered in combination with sodium pentobarbital $\left(28 \mathrm{mg} \mathrm{kg}^{-1}\right.$ ) also performed well, with $90 \%$ of the mice falling asleep $(p<0.01)$. The others did not exhibit an obvious effect. Fig. 3 shows that 2FHBA, SHBA, 2BHBA and 2NHBA combined with pentobarbital sodium ( $42 \mathrm{mg} \mathrm{kg}^{-1}$ ) significantly increased the sleep duration in mice (Fig. 3B, $p<0.05$ ), but the reduction in sleep latency was not obvious except for that with 2FHBA (Fig. 3A). From the above results, we concluded that 2FHBA displayed the best hypnotic activity among the new esters.

\subsection{Effect of 2FHBA on sleep in pentobarbital-treated mice}

A series of doses of 2FHBA ( $5 \mathrm{mg} \mathrm{kg}^{-1}, 10 \mathrm{mg} \mathrm{kg}^{-1}, 20 \mathrm{mg} \mathrm{kg}^{-1}$ and $50 \mathrm{mg} \mathrm{kg}^{-1}$ ) were designed to evaluate its hypnotic activity in combination with sodium pentobarbital $\left(42 \mathrm{mg} \mathrm{kg}^{-1}\right)$. The results showed that $10 \mathrm{mg} \mathrm{kg}^{-1}$ and $20 \mathrm{mg} \mathrm{kg}^{-1}$ of 2FHBA significantly prolonged the sleeping time ( $p<0.05$, Fig. $4 \mathrm{~B})$, but only administration of $10 \mathrm{mg} \mathrm{kg}^{-1}$ significantly decreased the sleep latency of the mice ( $p<0.05$, Fig. 4A). Furthermore, the
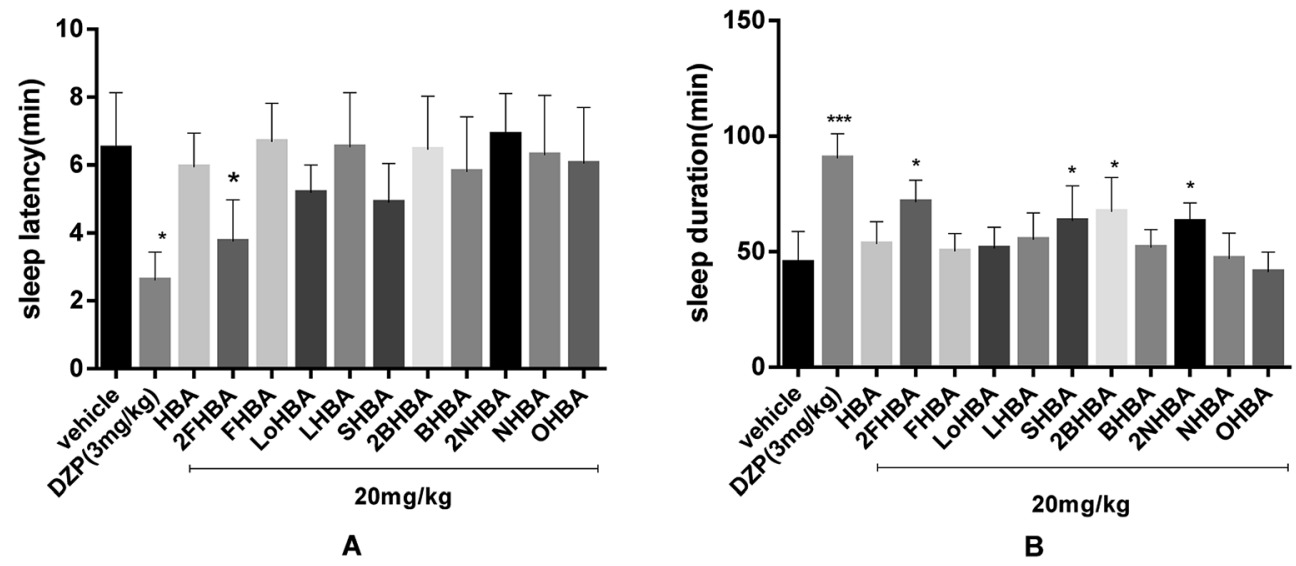

Fig. 3 The hypnotic effect of HBA esters (2FHBA, FHBA, LoHBA, LHBA, SHBA, 2BHBA, BHBA, 2NHBA, NHBA, and OHBA) co-administered with pentobarbital (42 $\mathrm{mg} \mathrm{kg}^{-1}$ ) on sleep in mice (10 in each group): the sleep latency (A) and the sleep duration (B); ${ }^{*} p<0.05, * * p<0.01$ and $* * * p<$ 0.001 compared with the vehicle group. 

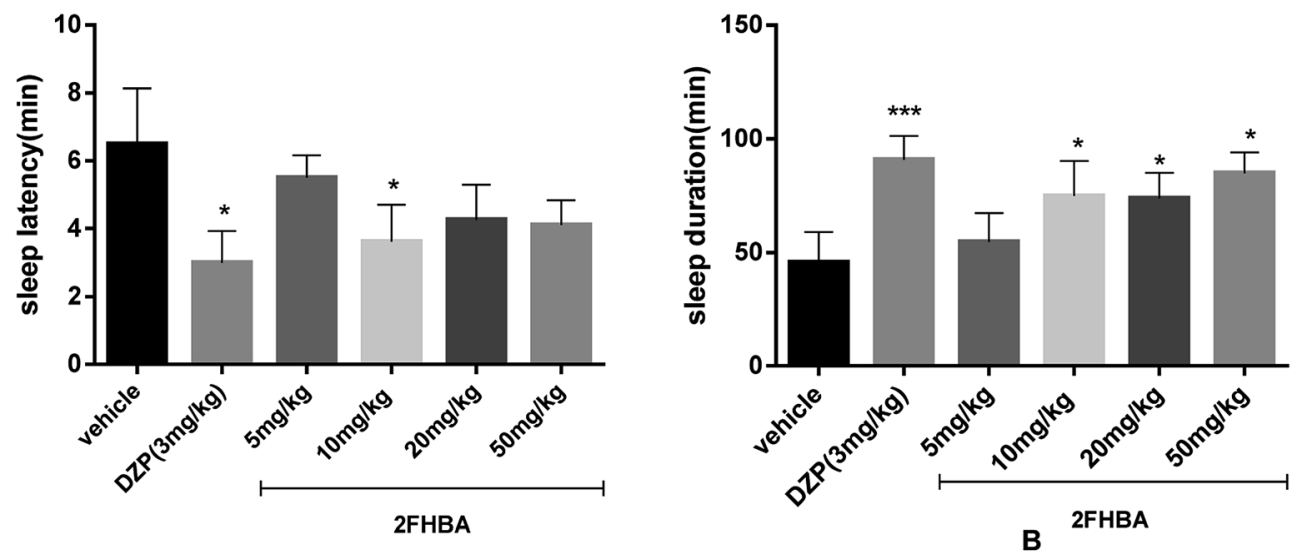

A

Fig. 4 The hypnotic effect of 2FHBA at different doses $\left(5 \mathrm{mg} \mathrm{kg}^{-1}, 10 \mathrm{mg} \mathrm{kg}^{-1}, 20 \mathrm{mg} \mathrm{kg}^{-1}\right.$ and $\left.50 \mathrm{mg} \mathrm{kg}^{-1}\right)$ co-administered with pentobarbital (42 $\mathrm{mg} \mathrm{kg}^{-1}$ ) in mice (10 in each group): the sleep latency (A) and the sleep duration (B); ${ }^{*} p<0.05, * * p<0.01$ and $* * * p<0.001$ compared with the vehicle group.

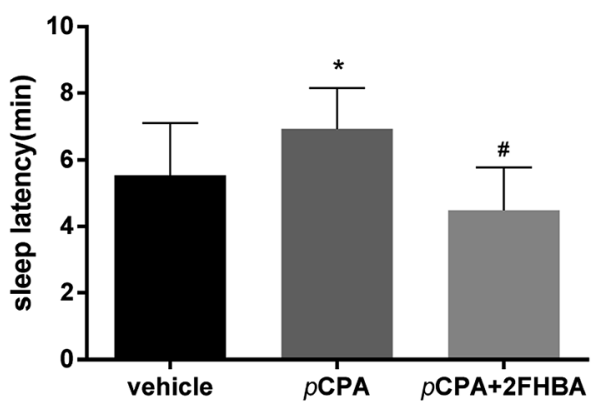

A

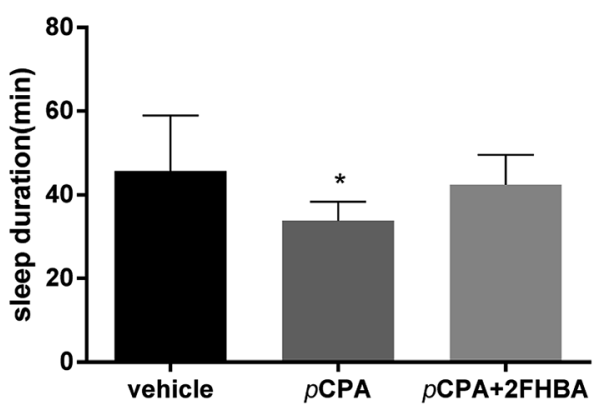

B

Fig. 5 Effect of 2FHBA (10 $\mathrm{mg} \mathrm{kg}^{-1}$ ) on pCPA-induced insomnia in pentobarbital-treated mice (10 in each group): the sleep latency (A) and sleep duration (B); all values are presented as mean \pm SD of the mean. ${ }^{*} p<0.05$ and ${ }^{* *} p<0.01$ compared with the vehicle group.

hypnotic effect of 2FHBA was dose-dependent, but this dependence is not obvious. $10 \mathrm{mg} \mathrm{kg}{ }^{-1}$ of 2 FHBA showed specific hypnotic activity, while $5 \mathrm{mg} \mathrm{kg}^{-1}$ represented the sub-hypnotic dose. These two doses were used in the following mechanism research.

\subsection{Effect of 2FHBA on $p$ CPA-induced insomnia in pentobarbital-treated mice}

Fig. 5 shows that after 4 days of $p$ CPA treatment $\left(100 \mathrm{mg} \mathrm{kg}^{-1}\right.$, i.p.), the sleep latency of mice was increased, and the sleep duration was reduced $(p<0.05)$, suggesting that a successful insomnia model was established. After administration of
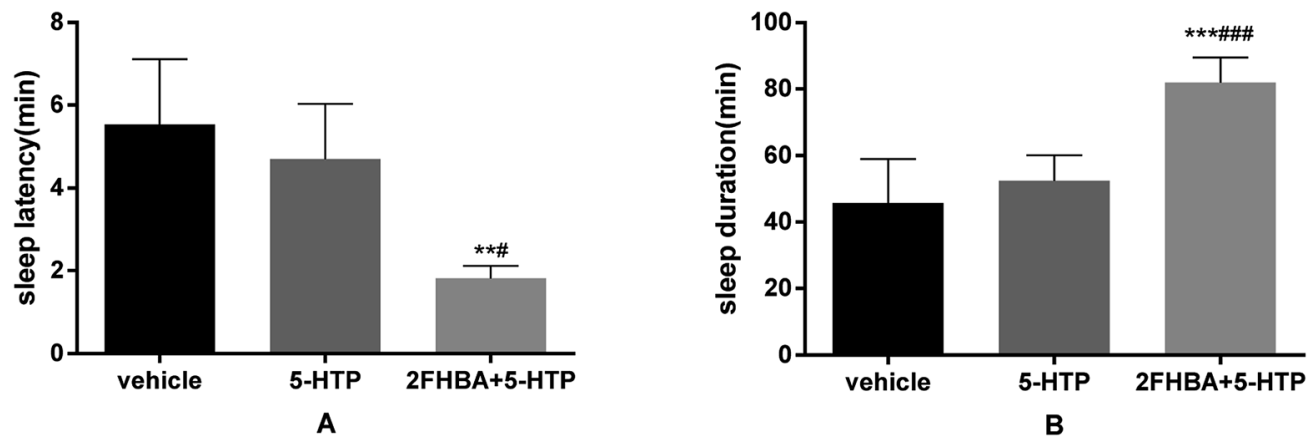

Fig. 6 Synergistic effect of 2FHBA ( $\left.5 \mathrm{mg} \mathrm{kg}^{-1}\right)$ with 5 -HTP $\left(2.5 \mathrm{mg} \mathrm{kg}^{-1}\right)$ on pentobarbital-treated sleep in mice (10 in each group): the sleep latency (A) and sleep duration (B); all values are presented as the mean $\pm \mathrm{SD}$. $* p<0.05, * * p<0.01$ and $* * * p<0.001$ compared with the vehicle

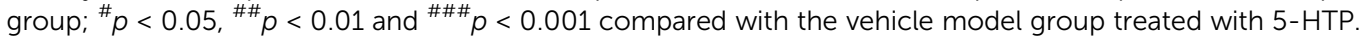




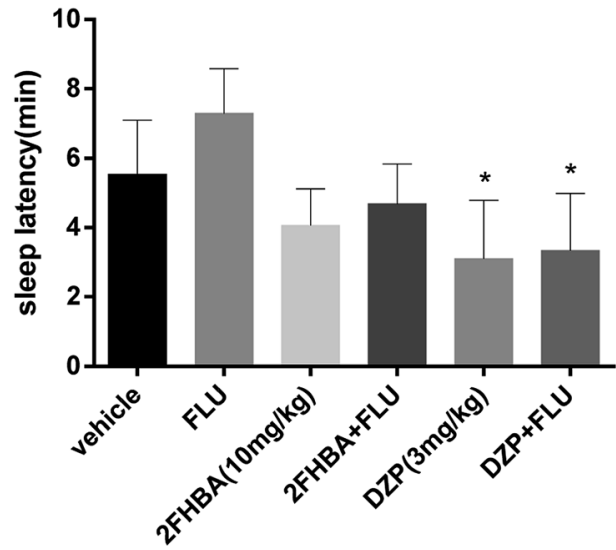

A

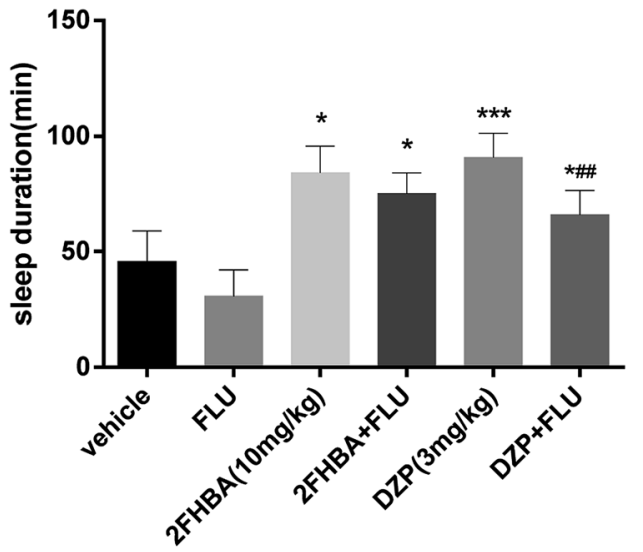

B

Fig. 7 Effect of 2FHBA (10 $\mathrm{mg} \mathrm{kg}^{-1}$ ) on FLU-induced insomnia in pentobarbital-treated mice (10 in each group): the sleep latency (A) and sleep duration (B); all values are presented as mean \pm SD. ${ }^{*} p<0.05$ and ${ }^{* *} p<0.01$ compared with the vehicle group; ${ }^{*} p<0.05$ and ${ }^{\# \#} p<0.01$, compared with the diazepam group $\left(3 \mathrm{mg} \mathrm{kg}^{-1}\right)$.

2FHBA (10 mg kg ${ }^{-1}$ ), the sleep latency was significantly shortened (Fig. 5A, $p<0.05$ ), but there was no statistically significant change in sleep duration, although it was prolonged (Fig. 5B).

\subsection{Synergic effects of 2FHBA and 5-HTP on sleep induced by pentobarbital}

In order to determine whether the hypnotic effect of 2FHBA was related to the serotonergic system, synergistic administration of sub-hypnotic doses of 2FHBA (5 $\left.\mathrm{mg} \mathrm{kg}^{-1}\right)$ and 5-HTP $(2.5 \mathrm{mg}$ $\mathrm{kg}^{-1}$ ) was performed. As shown in Fig. 6 , the sleep latency was significantly reduced $(p<0.01)$, and the sleep duration was significantly prolonged $(p<0.001)$. Combined with the results of the $p C P A$-induced model, this suggests that the serotonergic system might be involved in the hypnotic effects of 2 FHBA.

\subsection{Effect of 2FHBA on the hypnotic-reversing action of} flumazenil in pentobarbital-treated mice

Fig. 7 shows that administration of FLU $\left(8 \mathrm{mg} \mathrm{kg}^{-1}\right)$ alone slightly prolonged the sleep latency and shortened the sleep duration. In addition, the hypnotic effect of $2 \mathrm{FHBA}\left(10 \mathrm{mg} \mathrm{kg}^{-1}\right.$, $p<0.05$ ) was inhibited by FLU compared with the vehicle group, which was similar to the effect of DZP $\left(3 \mathrm{mg} \mathrm{kg}^{-1}\right)$ coadministered with FLU.

\subsection{Effect of 2FHBA on thiosemicarbazide-induced sleep disturbance in mice}

In this study, we could see an obvious insomnia model induced by TSC alone (8 $\left.\mathrm{mg} \mathrm{kg} \mathrm{kg}^{-1}, p<0.05\right)$. However, 2FHBA $\left(10 \mathrm{mg} \mathrm{kg}{ }^{-1}\right.$ ) reversed the TSC-induced insomnia. Compared with the TSC group, the sleep latency of the co-administration group was significantly shortened ( $p<0.05$, Fig. 8A) and the duration of sleep was significantly prolonged ( $p<0.01$, Fig. 8B). The above results suggested that the hypnotic effect of 2FHBA was related to the GABAergic system.

\subsection{Acute toxicity test results}

In the acute toxicity study, 2FHBA (1000, 2000 and $5000 \mathrm{mg}$ $\mathrm{kg}^{-1}$, i.g.) did not produce any mortality in the mice during the

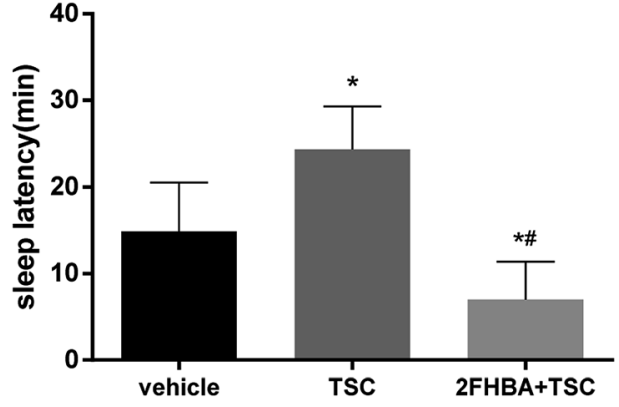

A

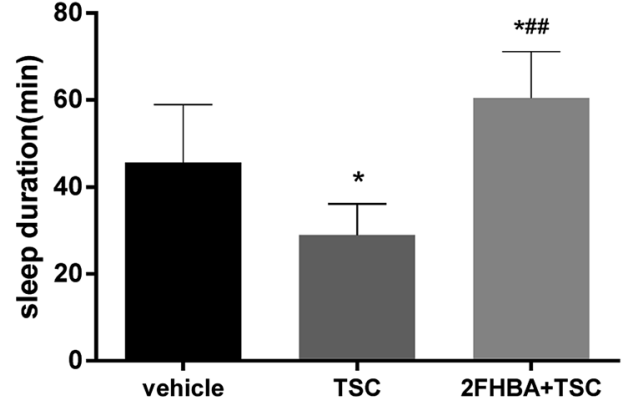

B

Fig. 8 Effect of 2FHBA (10 $\mathrm{mg} \mathrm{kg}^{-1}$ ) on TSC-induced insomnia in pentobarbital-treated mice (10 in each group): the sleep latency (A) and sleep duration (B); all values are presented as mean \pm SD. ${ }^{*} p<0.05$ and ${ }^{* *} p<0.01$ compared with the vehicle group; ${ }^{\#} p<0.05$ and ${ }^{\# \#} p<0.01$ compared with the TSC-treated group. 


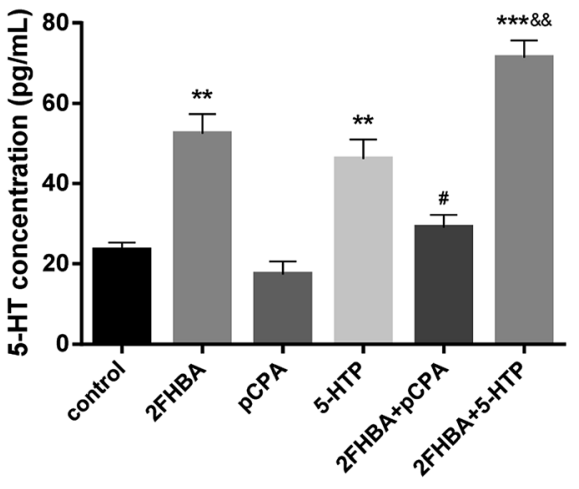

A

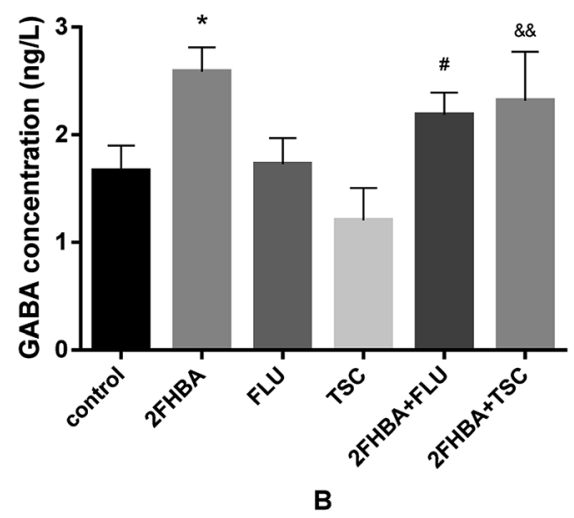

Fig. 9 The content of 5-HT in the brains of mice in the 2FHBA group, pCPA group, 5-HTP group, 2FHBA + pCPA group and 2FHBA+5-HTP group (A). The content of GABA in the brains of mice in the 2FHBA group, FLU group, TSC group, 2FHBA + FLU group and 2 FHBA + TSC group (B). The values represent the mean $\pm \mathrm{SD}(n=10$ in each group), compared with the control group, $* p<0.05, * * p<0.01$ and $* * * p<0.001 ;$ compared with the $p C P A\left(100 \mathrm{mg} \mathrm{kg}^{-1}\right.$, i.g.) (FLU (B) $\left(8 \mathrm{mg} \mathrm{kg}^{-1}\right)$ ) group, ${ }^{\#} p<0.05$; and compared with the $5-\mathrm{HTP}\left(2.5 \mathrm{mg} \mathrm{kg}^{-1}\right)\left(\right.$ TSC (B) (8 mg kg $\left.\left.{ }^{-1}\right)\right) \mathrm{group}$, ${ }^{8} p<0.05$ and ${ }^{\& \&} p<0.01$. One-way ANOVA, and a post-hoc Tukey test were used.

observation period. The 1000 and $2000 \mathrm{mg} \mathrm{kg}^{-1}$ treated groups did not show any adverse clinical signs compared to the control group. Meanwhile, the dose of $5000 \mathrm{mg} \mathrm{kg}^{-1}$ seemed to affect the female mice on the first day, as this group showed a small decrease in their intake of food and water, but this symptom gradually disappeared in the subsequent days. As the acute administration of 2FHBA did not produce death at the maximum dose of $5000 \mathrm{mg} \mathrm{kg}^{-1}$, the $\mathrm{LD}_{50}$ could not be estimated, and it was considered to be greater than $5000 \mathrm{mg} \mathrm{kg}^{-1}$. The early acute toxicity study of HBA and GAS also showed nontoxicity. ${ }^{35}$ Therefore, we considered 2FHBA to be non-toxic.

\subsection{Effects of 2FHBA on the levels of 5-HT and GABA in drug-treated mice}

To verify whether the sedative-hypnotic effect of 2FHBA was connected with the 5-HTergic and GABAergic systems, we detected the levels of 5-HT and GABA in the brains of the mice in the relevant administration groups. As Fig. 9A shows, the content of 5-HT was obviously increased in the 2FHBA group $(p<0.01)$. In the 2 FHBA combined with pretreatment with $p$ CPA group, the 5-HT level was obviously increased $(p<0.05)$ compared with that in the $p$ CPA group. In the 5-HTP group, the content of 5-HT was higher than that in the control group $(p<$ 0.01 ). In the combined use of 2FHBA and 5-HTP group, the 5-HT level was higher than that in the 5-HTP group $(p<0.01)$. Fig. 9B shows that the levels of GABA in the brains of the mice administered with 2FHBA were higher than the others, especially the control group $(p<0.05)$. The GABA level of 2FHBA combined with FLU was higher than that with FLU alone $(p<$ 0.05 ). The level of GABA in the 2 FHBA combined with TSC group was higher than that in the TSC group $(p<0.05)$.

\section{Discussion}

In this study, the original chemical structure of HBA was modified by reaction with organic acids in dichloromethane. We obtained 10 new compounds, which were screened for sedative and hypnotic activity for the first time. As is well-known, sleep is a sophisticated physiological process which is affected by a network of neuronal systems and is hard to reproduce in vitro. ${ }^{36,37}$ In this study, the sedative effects of the derivatives were determined through artificial screening using the spontaneous locomotor activity test. In addition, the classical behavioral pharmacology method, the pentobarbital-induced sleep test, was conducted to evaluate the hypnotic effect of the newly synthesized HBA esters. The present study showed that 2FHBA and SHBA significantly decreased the locomotor activity and potentiated the hypnotic effect of sodium pentobarbital, indicating their central nervous system depressant activity. Ultimately, 2FHBA, which had the strongest sedative and hypnotic activity, was selected for the subsequent experiments. Based on the results of dose screening, $10 \mathrm{mg} \mathrm{kg}^{-1}$ was selected as the effective hypnotic dose and $5 \mathrm{mg}$ $\mathrm{kg}^{-1}$ was selected as the sub-hypnotic dose.

The hippocampus plays an important role in sleep activity. Since serotonergic projections in the hippocampus are diffuse in nature ${ }^{38}$ the local effects of 5-HT are largely dependent on the 5-HT concentration. The hippocampus also modulates emotional processing in the central nervous system (CNS $)^{39}$ via diffuse serotonergic projections from the midbrain raphe nuclei. ${ }^{38}$ In fact, 5-HT imbalances are often correlated with psychological disorders such as insomnia, anxiety, depression, and psychosis. ${ }^{40-42}$ Interestingly, 5-HT receptors also form homodimers or heterodimers among themselves or other Gprotein-coupled receptors (GPCRs), respectively, which greatly enhances the complexity of their functions. ${ }^{43} p \mathrm{CPA}$ is an inhibitor of 5-HT synthesis. ${ }^{44}$ In this study, the content of 5-HT in the brain was significantly decreased after $p$ CPA was used alone, while 2FHBA increased the content of 5-HT. There was no doubt that the increase in 5-HT level contributed significantly to the sedative and hypnotic effect. ${ }^{45} 5$-HTP, which is the ratelimiting precursor in 5-HT biosynthesis, is used as an oral supplement to enhance serotonin levels in humans. ${ }^{46}$ In this study, co-administration of 5-HTP with 2FHBA significantly shortened the sleep latency and increased the duration of sleep 
in mice, and the content of 5-HT in the brains of the mice increased significantly compared with that in the control group, suggesting that 2FHBA exerted its sedative and hypnotic effect via the 5-HT system.

In addition to 5-HT, GABA is also considered as another important neurotransmitter associated with sleep modulation. ${ }^{47}$ The $\gamma$-aminobutyric acid-A $\left(\mathrm{GABA}_{\mathrm{A}}\right)$ receptor is a ligandgated ion channel that modulates the levels of anxiety, insomnia, and memory. ${ }^{48}$ The $\mathrm{GABA}_{\mathrm{A}}$ receptor is a heteropentameric membrane protein that forms a GABA-gated chloride channel and is composed of several classes of subunits $(\alpha, \beta, \gamma, \delta \text {, and } \varepsilon)^{49,50}$ Pharmacological studies suggested that classic benzodiazepines and other $\mathrm{GABA}_{\mathrm{A}}$ receptor positive modulators reduce anxiety and improve sleeping. ${ }^{51}$ Diazepam, as a representative sedative-hypnotic drug, releases GABA through binding with the $\mathrm{GABA}_{\mathrm{A}}$-BZD receptor. In contrast, flumazenil as a specific benzodiazepine-derived (BZD) antagonist, can effectively induce insomnia. In this study, 2FHBA exhibited a stable hypnotic effect. We sought to determine the possible mechanisms of action. The hypnotic effects of 2FHBA were blocked by the $\mathrm{GABA}_{\mathrm{A}}$ receptor antagonist flumazenil, which indicated that the hypnotic activity of 2 FHBA was attributed to the modulation of the $\mathrm{GABA}_{\mathrm{A}}-\mathrm{BZD}$ receptor through the GABAergic system. As a central nervous stimulant, thiosemicarbazide is an inhibitor of glutamate decarboxylase, and its application will cause a reduction in the GABA content in the brain. ${ }^{34}$ From the above results, it was shown that 2FHBA can significantly improve insomnia caused by TSC, and 2FHBA with TSC treatment can significantly increase the content of GABA in the brain, which demonstrated that the hypnotic effect of 2FHBA was related to the GABAergic system. In order to assess the potential druggability of $2 \mathrm{FHBA}$, the acute toxicity of 2FHBA was detected, and the results showed that the mice did not exhibit any signs of toxicity or mortality despite the dose being up to $5000 \mathrm{mg} \mathrm{kg}^{-1}$, so we considered 2FHBA to be safe.

\section{Conclusions}

In summary, 10 HBA derivatives were synthesized with simple control, and their sedative-hypnotic activities were evaluated. The results showed that 2FHBA showed the strongest sedativehypnotic effects, and its hypnotic effect might be related to the serotonergic system and GABAergic system. Overall, this study demonstrated that the structural modification of HBA by esterification might be an effective method for its application in altering central nervous system function. 2FHBA has potential to be developed as an agent for insomnia therapy.

\section{Conflicts of interest}

The authors declare no conflict of interest.

\section{Abbreviations}

EDCI 1-Ethylethyl-3-(3-dimethyllaminopropyl) carbodiimide hydrochloride
DMAP 4-Dimethylaminopyridine

HBA 4-Hydroxybenzyl alcohol

2FHBA 4-Hydroxybenzyl alcohol 3-furancarboxylic acid diester

FHBA 4-Hydroxybenzyl alcohol 3-furoate

LoHBA 4-Hydroxybenzyl alcohol linoleic acid diester

SHBA 4-Hydroxybenzyl alcohol sorbic acid diester

LHBA 4-Hydroxybenzyl alcohol lauric acid diester

BHBA 4-Hydroxybenzyl alcohol benzoate

2BHBA 4-Hydroxybenzyl alcohol benzoic acid diester

2NHBA 4-Hydroxybenzyl alcohol 2-naphthoic acid diester

NHBA 4-Hydroxybenzyl alcohol 2-naphthoate

OHBA 4-Hydroxybenzyl alcohol oleic acid diester

SLT Spontaneous locomotor activity test

DZP Diazepam

pCPA $p$-Chlorophenylalanine

BZD Benzodiazepine-derived

5-HT 5-Hydroxytryptamine

5-HTP 5-Hydroxytryptophan

GABA $\gamma$-Aminobutyric acid

GABA $_{A} \quad \gamma$-Aminobutyric acid-A

FLU Flumazenil

TSC Thiosemicarbazide

CNS Central nervous system

GPCRs G-protein-coupled receptors

\section{Acknowledgements}

This work was supported by the Jilin Provincial Science and Technology Development Project (20180520060JH), the Jilin Provincial Education Department Fund Project (JJKH20170321KJ), the National Key Research and Development Project (2016YFC0500300) and the Jilin Provincial Key Scientific and Technological Project (20170204017YY).

\section{References}

1 K. B. Hong, Y. Park and H. J. Suh, Sleep-promoting effects of the GABA/5-HTP mixture in vertebrate models, Behav. Brain Res., 2016, 310, 36-41.

2 H. Wen, et al., Methyl 2-(2-(4-formylphenoxy)acetamido)-2substituted acetate derivatives: a new class of acetylcholinesterase inhibitors, Bioorg. Med. Chem. Lett., 2007, 17(8), 2123-2125.

3 Y. Zhang, et al., NHBA isolated from Gastrodia elata exerts sedative and hypnotic effects in sodium pentobarbitaltreated mice, Pharmacol., Biochem. Behav., 2012, 102(3), 450-457.

4 Y. Shi, et al., N(6)-(3-methoxyl-4-hydroxybenzyl) adenine riboside induces sedative and hypnotic effects via GAD enzyme activation in mice, Pharmacol., Biochem. Behav., 2014, 126, 146-151.

5 C. L. Hsieh, et al., Gastrodia elata modulated activator protein 1 via c-Jun $\mathrm{N}$-terminal kinase signaling pathway in kainic acid-induced epilepsy in rats, J. Ethnopharmacol., 2007, 109(2), 241-247.

$6 \mathrm{~J}$. H. Ha, et al., 4-Hydroxybenzaldehyde from Gastrodia elata B1. is active in the antioxidation and GABAergic 
neuromodulation of the rat brain, J. Ethnopharmacol., 2000, 73(1-2), 329-333.

7 J. W. Jung, et al., Anxiolytic-like effects of Gastrodia elata and its phenolic constituents in mice, Biol. Pharm. Bull., 2006, 29(2), 261-265.

8 S. H. Lin, et al., Down-regulation of Slit-Robo pathway mediating neuronal cytoskeletal remodeling processes facilitates the antidepressive-like activity of Gastrodia elata Blume, J. Agric. Food Chem., 2014, 62(43), 10493-10503.

9 C. F. Ng, et al., The Aqueous Extract of Rhizome of Gastrodia elata Protected Drosophila and PC12 Cells against BetaAmyloid-Induced Neurotoxicity, J. Evidence-Based Complementary Altern. Med., 2013, 516741.

10 E. Descamps, et al., Experimental stroke protection induced by 4-hydroxybenzyl alcohol is cancelled by bacitracin, Neurosci. Res., 2009, 64(2), 137-142.

11 E. J. Shin, et al., Effects of Gastrodia elata $\mathrm{Bl}$ on phencyclidine-induced schizophrenia-like psychosis in mice, Curr. Neuropharmacol., 2011, 9(1), 247-250.

12 Y. U. Lei, Y. S. Shen and H. C. Miao, Study on the Anti-vertigo Function of Polysaccharides of Gastrodia elata and Polysaccharides of Armillaria mellea, Chin. J. Inf. Tradit. Chin. Med., 2006, 8(13), 29-36.

13 C. S. Ding, et al., Study of a glycoprotein from Gastrodia elata: its effects of anticoagulation and antithrombosis, Zhongguo Zhongyao Zazhi, 2007, 32(11), 1060-1064.

14 T. Y. Jung, et al., Protective effects of several components of Gastrodia elata on lipid peroxidation in gerbil brain homogenates, Phytother. Res., 2007, 21(10), 960-964.

15 O. H. Lee, et al., Effects of Acidic Polysaccharides from Gastrodia Rhizome on Systolic Blood Pressure and Serum Lipid Concentrations in Spontaneously Hypertensive Rats Fed a High-Fat Diet, Int. J. Mol. Sci., 2012, 13(1), 698-709.

$16 \mathrm{~J}$. Y. Lee, et al., Anti-inflammatory action of phenolic compounds from Gastrodia elata root, Arch. Pharmacal Res., 2006, 29(10), 849-858.

17 S. M. Hwang, et al., Anti-inflammatory effect of Gastrodia elata rhizome in human umbilical vein endothelial cells, Am. J. Chin. Med., 2009, 37(02), 395-406.

$18 \mathrm{Y}$. Hu, C. Li and W. Shen, Gastrodin alleviates memory deficits and reduces neuropathology in a mouse model of Alzheimer's disease, Neuropathology, 2014, 34(4), 370-377.

$19 \mathrm{X}$. Tong, et al., WSS45, a sulfated $\alpha$-D-glucan, strongly interferes with Dengue 2 virus infection in vitro, Acta Pharmacol. Sin., 2010, 31(5), 585-592.

$20 \mathrm{G}$. Shu, et al., Gastrodin stimulates anticancer immune response and represses transplanted $\mathrm{H} 22$ hepatic ascitic tumor cell growth: involvement of NF- $\mathrm{B}$ signaling activation in CD4+ T cells, Toxicol. Appl. Pharmacol., 2013, 269(3), 270-279.

21 W. Zhang, Y. X. Sheng and J. L. Zhang, Determination and pharmacokinetics of gastrodin and $p$-hydroxybenzylalcohol after oral administration of Gastrodia elata Bl. extract in rats by high-performance liquid chromatographyelectrospray ionization mass spectrometric method, Phytomedicine, 2008, 15(10), 844-850.
22 Chinese Pharmacopoeia Commission, Pharmacopoeia of the People's Republic of China, 2015, p. 58.

23 Y. J. Mo and D. Shi-Xian, Pharmacological study on Gastrodia elata Blume.2. effects of synthetic gastrodin and its genin on the heart and small intestine, Acta Bot. Yunnanica, 1980, 2(2), 230-234.

24 W. C. Chen, et al., Anti-depressant effects of Gastrodia elata Blume and its compounds gastrodin and 4-hydroxybenzyl alcohol, via the monoaminergic system and neuronal cytoskeletal remodeling, J. Ethnopharmacol., 2016, 182, 190-199.

25 B. W. Kim, et al., Modulation of LPS-stimulated neuroinflammation in BV-2 microglia by Gastrodia elata: 4hydroxybenzyl alcohol is the bioactive candidate, $J$. Ethnopharmacol., 2012, 139(2), 549-557.

26 M. W. Laschke, et al., 4-Hydroxybenzyl alcohol: a novel inhibitor of tumor angiogenesis and growth, Life Sci., 2013, 93(1), 44-50.

27 S. S. Yu, et al., Neuroprotective effect of 4-hydroxybenzyl alcohol against transient focal cerebral ischemia via antiapoptosis in rats, Brain Res., 2010, 1308(3), 167-175.

28 Q. L. Guo, et al., 4-Hydroxybenzyl-substituted glutathione derivatives from Gastrodia elata, J. Asian Nat. Prod. Res., 2015, 17(5), 439-454.

29 R. Kodela, et al., Synthesis and biological activity of acetylprotected hydroxybenzyl diethyl phosphates (EHBP) as potential chemotherapeutic agents, Bioorg. Med. Chem. Lett., 2011, 21(23), 7146-7150.

$30 \mathrm{~S}$. Ahmed, et al., Synthesis and biochemical evaluation of a range of sulfonated derivatives of 4-hydroxybenzyl imidazole as highly potent inhibitors of rat testicular 17alpha-hydroxylase/17,20-lyase (P-450(17alpha)), Bioorg. Med. Chem. Lett., 2009, 19(16), 4698-4701.

31 L. Zha, et al., Analysis of parameters of serum concentration and pharmacokinetic of liposome and aqueous solution of total ginsenoside of ginseng stems and leaves in rats, Zhongguo Zhongyao Zazhi, 2017, 1957-1963.

32 E. B. Cai, et al., The synthesis and evaluation of arctigenin amino acid ester derivatives, Chem. Pharm. Bull., 2016, 64(10), 1466-1473.

33 OECD, Guidelines for the Testing of Chemicals/Section 4: Health Effects Test No. 423, Acute Oral Toxicity - Acute Toxic Class Method, Organisation for Economic Co-operation and Development, Paris, France, 2002.

34 Y. Öztürk, et al., Effects of Hypericum perforatum L. and Hypericum calycinum L. extracts on the central nervous system in mice, Phytomedicine, 1996, 3(2), 139-146.

35 S. X. Deng and Y. Q. Mo, Pharmacological studies on Gastrodia elata Bluma.1. the sedative and anticonvulsant effects of synthetic gastrodin and its genin, Acta Bot. Yunnanica, 1979, 2(1), 66-73.

36 P. M. Fuller, J. J. Gooley and C. B. Saper, Neurobiology of the sleep-wake cycle: sleep architecture, circadian regulation, and regulatory feedback, J. Biol. Rhythms, 2006, 21(6), 482493.

37 M. Zhu, et al., Application of radioligand receptor binding assays in the search for CNS active principles from 
Chinese medicinal plants, J. Ethnopharmacol., 1996, 54(2-3), 153-164.

38 R. Y. Moore and A. E. Halaris, Hippocampal innervation by serotonin neurons of the midbrain raphe in the rat, $J$. Comp. Neurol., 1975, 164(2), 171-183.

39 D. M. Bannerman, et al., Regional dissociations within the hippocampus-memory and anxiety, Neurosci. Biobehav. Rev., 2004, 28(3), 273-283.

40 E. Dale, et al., Effects of serotonin in the hippocampus: how SSRIs and multimodal antidepressants might regulate pyramidal cell function, CNS Spectr., 2016, 21(2), 143-161.

41 M. A. Geyer and F. X. Vollenweider, Serotonin research: contributions to understanding psychoses, Trends Pharmacol. Sci., 2008, 29(9), 445-453.

42 K. Herrickdavis, Functional Significance of Serotonin Receptor Dimerization, Exp. Brain Res., 2013, 230(4), 375386.

43 A. R. Green, Neuropharmacology of 5-hydroxytryptamine, $\mathrm{Br}$. J. Pharmacol., 2006, 147(S1), S145-S152.

44 A. A. Borbély and H. U. Neuhaus, Sleep-deprivation: effects on sleep and EEG in the rat, J. Comp. Physiol., 1979, 133(1), 71-87.
45 R. G. Peñalva, et al., Effect of sleep and sleep deprivation on serotonergic neurotransmission in the hippocampus: a combined in vivo microdialysis/EEG study in rats, Eur. J. Neurosci., 2003, 17(9), 1896-1906.

46 C. P. Lynn-Bullock, et al., The effect of oral 5-HTP administration on 5-HTP and 5-HT immunoreactivity in monoaminergic brain regions of rats, J. Chem. Neuroanat., 2004, 27(2), 129-138.

47 A. N. Bateson, Further potential of the GABA receptor in the treatment of insomnia, Sleep Med., 2006, 7(1), S3-S9.

$48 \mathrm{~J}$. Liu, et al., GABA and 5-HT systems are implicated in the anxiolytic-like effect of spinosin in mice, Pharmacol., Biochem. Behav., 2015, 128, 41-49.

49 E. A. Barnard, et al., Molecular Biology of the $\mathrm{GABA}_{\mathrm{A}}$ Receptor, Adv. Exp. Med. Biol., 1988, 295-308.

$50 \mathrm{R}$. W. Olsen and W. Sieghart, International Union of Pharmacology. LXX. Subtypes of gamma-aminobutyric $\operatorname{acid}(\mathrm{A})$ receptors: classification on the basis of subunit composition, pharmacology, and function. Update, Pharmacol. Rev., 2008, 60(3), 243-260.

51 C. Belzung and G. Griebel, Measuring normal and pathological anxiety-like behaviour in mice: a review, Behav. Brain Res., 2001, 125(1-2), 141-149. 